\title{
STRATEGI KEBIJAKAN PEMERINTAH KABUPATEN TEMANGGUNG DALAM PEMULIHAN PARIWISATA DI MASA PANDEMI COVID-19
}

\author{
Wihardiyani \\ Magister Kajian Pariwisata. Sekolah Pascasarjana. Universitas Gadjah Mada \\ wihardiyani@mail.ugm.ac.id
}

\begin{abstract}
The COVID-19 outbreak has hit Indonesia and the world since the end of 2019 which started in Wuhan, China. The existence of a pandemic that is increasingly spreading has caused the paralysis of all activities, this cannot be separated from the tourism sector. tourism activities that stop completely cause economic losses to lay off workers. So that in handling it requires a policy from the Central Government to deal with the spread of the Covid-19 virus. Government policy is a policy or action submitted by the government, both the Regional Government and the Central Government in order to solve the problems that are happening in the community. The purpose of this paper is to find out the strategies used by the Temanggung Regency Government in handling tourism recovery after the prolonged COVID-19 pandemic. In this writing technique using the Literature Review method with secondary data originating from valid sources both from official websites to news portals. The results obtained are that various strategies have been carried out by the Temanggung Regency Government in the recovery of the tourism sector, such as implementing policies to cooperating in order to improve the management of a tourist destination.
\end{abstract}

Keywords: policy strategy, impact of covid-19, Renja 2021

\section{PENDAHULUAN}

Covid-19 merupakan wabah atau pandemi yang ada sejak Desember 2019, dimana virus tersebut menyebar ke seluruh dunia hingga masuk di Indonesia. Wabah pandemi covid-19 mengakibatkan lumpuhnya beberapa sektor terkhususnya adalah sektor pariwisata. Berbagai hal dalam sektor pariwisata menjadi mati dan tak berdaya akibat dari adanya pandemi covid19 karena ketakukan masyarakat dengan adanya pandemi covid-19. Masyarakat merasa takut tertular pandemi tersebut yang mana dapat menyebar melalui bersentuhan maupun bersin. Hal tersebut menjadikan Pemerintah memberlakukan PPKM atau Pemberlakukan Pembatasan Kegiatan Masyarakat terhadap segala aktivias 
masyarakat. Pemberlakuan PPKM tersebut menimbulkan berbagai dampak kepada masyarakat, dalam hal ini adalah sektor Pariwisata. Atas pemberlakuan PPKM tersebut mengakibatkan penutupan destinasi pariwisata.

$$
\text { Pembelakukaan PPKM juga }
$$

berlaku di Kabupaten Temanggung Jawa Tengah. Hal ini mengakibatkan seluruh destinasi wisata di Kabupaten Temanggung mengalami kelumpuhan serta kemacetan. Masyarakat berbondong-bondong menutup destinasi wisata untuk mengurangi kemungkinan terjadinya penularan melalui kerumunan serta atas dasar kebijakan Pemerintah Kabupaten Temanggung yang menerbitkan surat edaran terkait dengan pembatasan kegiatan masyarakat salah satunya adalah Surat Edaran Nomor SP/174/360/01/V/2021 terkait dengan Perpanjangan Penerapan Pemberlakuan Pembatasan Kegiatan Masyarakat (PPKM) Berbasis Mikro untuk Pengendalian Penyebaran Corona Virus Disease 2019 (Covid-19) di Kabupaten Temanggung. Dalam surat edaran tersebut disampaikan bahwa kegiatan pariwisata yang menimbulkan kerumunan hanya diperbolehkan $30 \%$ pengunjung.
Pembatasan-pembatasan kegiatan masyarakat tersebut tidak menjadikan pemerintah Kabupaten Temanggung berdiam diri tanpa melakukan berbagai persiapan. Adanya pandemi covid-19 menjadikan Pemerintah melakukan berbagai upaya dan perbaikan yang mana dapat memberikan kemudahan bagi masyarakat dan pengelola tempat wisata sehingga dapat memberikan dorongan dalam menaikkan kembali sektor pariwisata di Kabupaten Temanggung. Berbagai upaya dan strategi dibutuhkan oleh baik pemerintah daerah maupun pemerintah pusat seperti halnya di Kabupaten Temanggung.

Kebijakan menurut Friedrick adalah tindakan yang diusulkan seseorang, kelompok maupun pemerintah dalam suatu lingkungan dengan menunjukkan adanya hambatan maupun kesempatan terhadap pelaksanaan usulan kebijakan dalam rangka mencapai tujuan tertentu. Sedangkan menurut Anderson, kebijakan merupakan serangkaian tindakan yang memiliki tujuan utama untuk dicapai dan dilaksanakan oleh seseorang baik secara kelompok maupun individu untuk memecahkan permasalahan yang ada (Suwitri; 2008). Berdasarkan pengertian di atas maka dapat diambil kesimpulan bahwa kebijakan pemerintah 


\section{Sabbhata Yatra}

Jurnal Pariwisata dan Budaya

Volume 2 Nomor 2 Desember 2021

adalah suatu rangkaian atau tindakan yang diselenggarakan oleh Pemerintah, baik Pemerintah Pusat maupun Pemerintah Daerah dalam rangka menangani suatu permasalahan yang sedang timbul di dalam masyarakat.

Dalam menentukan sebuah

kebijakan hendaknya perlu memperhatikan beberapa kriteria. Seperti halnya yang disampaikan oleh Abidin (dalam Herbudin, 2016) yang mengemukakan kriteria kebijakan diantaranya adalah sebagai berikut:

a. Efektifitas. Efektivitas dalam hal ini adalah untuk mengukur sasaran atau tujuan yang akan dicapai dengan adanya kebijakan yang mana dapat menghasilkan tujuan akhir sesuai dengan yang telah ditetapkan.

b. Efisiensi. Efisiensi yang digunakan adalah anggaran dalam pencapaian tujuan yang telah ditetapkan dalam suatu pemerintahan.

c. Cukup. Cukup dalam hal ini berarti kebijakan yang telah diterapkan tersebut mencapai hasil yang telah ditetapkan dengan sumber anggaran yang tidak melampui batasannya.

d. Terjawab. Maksud dari terjawab disini adalah kebijakan yang dibuat oleh pemerintah tersebut memenuhi kebutuhan maupun memecahkan permasalahan yang ada dalam masyarakat.

Tugas dan fungsi Dinas Kebudayaan dan Pariwisata Kabupaten Temanggung tertuang dalam Peraturan Bupati Temanggung Nomor 24 Tahun 2021 tentang Tugas dan Fungsi Dinas Kebudayaan dan Pariwisata Kabupaten Temanggung. Dalam hal ini adalah bidang pariwisata tertuang pada pasal 15 tentang tugas bidang pariwisata yaitu melakukan pengkoordinasian, penyusunan program dan pelaksanaan kebijakan, penyelenggaraan, pengendalian, pemantauan, pembinaan, penyelenggaraan serta evaluasi dan pelaporan meliputi bidang-bidang destinasi pariwisata, pemasaran, sumber daya dan ekonomi kreatif.

Selain itu dalam pasal 16 menyampaikan bahwa fungsi dari bidang pariwisata Kabupaten Temanggung diantaranya adalah sebagai berikut:

a. Perumusan program kebijakan teknis di bidang destinasi pariwisata;

b. Perumusan program bahan pengelolaan destinasi pariwisata;

c. Penyusunan kebijakan pengembangan destinasi pariwisata; 
d. Pelaksanaan kebijakan, fasilitasi, koordinasi daya tarik destinasi wisata, pemasaran, sumber daya dan ekonomi kreatif;

e. Pengelolaan dan pengembangan destinasi wisata dan kawasan strategis pariwisata daerah;

f. Penyusunan kebijakan teknis pemasaran kepariwisataan, seni, dan budaya;

g. Pembinaan pelaku usaha kepariwisataan;

h. Pelaksanaan monitoring, evaluasi dan penyusunan pelaporan destinasi pariwisata, pemasaran, sumber daya dan ekonomi kreatif; dan

i. Pelaksanaan tugas kedinasan lain yang diberikan oleh kepala dinas sesuai dengan fungsinya.

\section{METODE}

Penelitian dalam makalah ini menggunakan metode literature review. Penggunaan literature review dengan sumber data sekunder yang mana diperoleh dari berbagai sumber yang kredibel dan ilmiah seperti paper ilmiah yang berada dalam sebuah jurnal yang memiliki tingkat kredibel nasional dan internasional. Selain itu penulis juga menggunakan sumbersumber lain seperti website resmi dan lembaga terkait serta portal berita maupun $e$ - book yang telah dipublikasikan secara kredibel.

\section{HASIL DAN PEMBAHASAN}

Kabupaten Temanggung terletak di tengah-tengah Propinsi Jawa Tengah dengan bentangan Utara ke Selatan 46,8 km dan Timur ke Barat $43 \mathrm{~km}$. Kabupaten Temanggung dengan luas wilayah 870,65 km2 (87.065 Ha). Wilayah Kabupaten Temanggung secara geoekonomis dilalui oleh 3 jalur pusat kegiatan ekonomi, yaitu Semarang (77 km), Yogyakarta (64 km), dan Purwokerto $(134 \mathrm{~km})$. Permukaan wilayah Kabupaten Temanggung termasuk ke dalam golongan dataran tinggi. Pola topografi wilayah secara umum mirip sebuah cekungan raksasa yang terbuka pada bagian Tenggara, di bagian Selatan dan Barat dibatasi oleh 2 buah gunung yaitu Gunung Sumbing (3.340 m dpl) dan Gunung Sindoro (3.115 m dpl). Bagian Utara dibatasi oleh sebuah pegunungan kecil yang membujur dari timur laut kearah tenggara. Sebagian wilayah Kabupaten berada pada ketinggian $500 \mathrm{~m} 1000 \mathrm{~m}(24,3 \%)$, luasan areal ini merupakan daerah lereng Gunung Sindoro dan Gunung Sumbing yang terhampar dari sisi Selatan, Barat sampai dengan Utara 
Jurnal Pariwisata dan Budaya

Volume 2 Nomor 2 Desember 2021

wilayah (portal.temanggungkab.go.id;

Atraksi yang mana dapat dijabarkan bahwa 2015). berdasarkan data Renja pada tahun 2020,

Kabupaten Temanggung berada Kabupaten Temanggung memiliki 17 hotel diantara 2 kawasan wisata besar yaitu diantara Kabupaten Magelang yang memiliki Candi Borobudur sebagai tujuan wisata utama dan Kabupaten Wonosobo yang memiliki Dataran Tinggi Dieng sebagai tujuan utama untuk kegiatan berwisata, sehingga Kabupaten Temanggung menjadi daerah ampiran tujuan wisata belum menjadi daerah tujuan wisata (portal.temanggungkab.go.id; 2015). Hal tersebut menjadi salah satu permasalahan yang perlu untuk dilakukan tindak lanjutnya yang mana hendaknya untuk menjadi tujuan utama wisata bukan hanya sebagai tempat singgah wisatawan. Kabupaten Temanggung sendiri apabila dilihat dari 3A aspek dalam pariwisata yaitu Amenitas, Aksebilitas, dan dan 2 homestay yang tersebar di seluruh wilayah. Selain itu tingkat aksebilitas daerah Temanggung dapat diakses melalui berbagai arah yaitu dari Semarang, Magelang, Solo, Yogyakarta, Kendal, Purwokerto, Banjarnegara, Sukorejo, Waleri, Pekalongan hingga Wonosobo (portal.temanggungkab.go.id; 2015).

Sedangkan untuk atraksinya, Kabupaten Temanggung sendiri memiliki berbagai jenis wisata yang ditawarkan. Wisata-wisata tersebut diantaranya terdiri dari wisata alam, wisata bangunan bersejarah, hingga wisata buatan. Berikut merupakan data wisata yang tercatat di dalam Renja Kabupaten Temanggung: 
Sabbhata Yatra

Jurnal Pariwisata dan Budaya

Volume 2 Nomor 2 Desember 2021

Data Potensi Wisata/Daya Tarik Wisata

KabupatenTemanggung

\begin{tabular}{|c|c|c|c|}
\hline NO & NAMA OBYEK WISATA & TEMPAT & $\begin{array}{c}\text { KET } \\
\text { (berkembang/ } \\
\text { potensi) }\end{array}$ \\
\hline \multicolumn{4}{|c|}{ OBYEK WISATA ALAM } \\
\hline 1 & Gowa Lawa & Kec. Bejen & Potensi \\
\hline 2 & Curug Lawe & Kec. Gemawang & Potensi \\
\hline 3 & Curug Onje & Kec. Bejen & Potensi \\
\hline 4 & Perkebunan Bojongrejo & Kec. Bejen & Potensi \\
\hline 5 & Curug Guwung & Kec. Bejen & Potensi \\
\hline 6 & Bukit Kembang Arum & Kec. Bejen & Dikembangkan \\
\hline 7 & Pesona Wagir Bawang & Kec. Tretep & Dikembangkan \\
\hline 8 & Air Terjun Trocoh (Surodipo) & Kec. Wonoboyo & Dikembangkan \\
\hline 9 & Wana Wisata Jumprit (wapit) & Kec. Ngadirejo & Dikembangkan \\
\hline 10 & Mata Air Jumprit & Kec. Ngadirejo & Dikembangkan \\
\hline 11 & Sendang Sidukun & Kec. Parakan & Potensi \\
\hline 12 & Pesona Alam Sewu & Kec. Ngadirejo & Potensi \\
\hline 13 & Bukit Sindumoyo & Kec. Ngadirejo & Potensi \\
\hline 14 & Wisata Bansari & Kec. Bansari & Dikembangkan \\
\hline 15 & Watu Mlongso & Kec. Kledung & Potensi \\
\hline 16 & Sedadap & Kec. Kledung & Potensi \\
\hline 17 & Posong & Kec. Kledung & Dikembangkan \\
\hline 18 & Watu Kelir & Kec. Kledung & Potensi \\
\hline 19 & Pendakian Gunung Sindoro & Kec. Kledung & Potensi \\
\hline 20 & Sedengkeng Pass & Kec. Kledung & Potensi \\
\hline 21 & Goa Wonotirto & Kec. Bulu & Potensi \\
\hline 22 & Watu Wayang & Kec. Bulu & Potensi \\
\hline 23 & Perkebunan Gesing & Kec. Kandangan & Potensi \\
\hline 24 & Sigrowong & Kec. Kandangan & Potensi \\
\hline 25 & Curug Mataraman & Kec. Kandangan & Potensi \\
\hline 26 & Perkebunan Rowoseneng & Kec. Kandangan & Potensi \\
\hline 27 & Watu Layah & Kec. Kandangan & Potensi \\
\hline 28 & Watu Angkrik & Kec. Kandangan & Potensi \\
\hline 29 & Curug Goa Lawa & Kec. Kranggan & Potensi \\
\hline 30 & Curug Kreo & Kec. Kranggan & Potensi \\
\hline 31 & Gardu Pandang Simpar & Kec. Tretep & Dikembangkan \\
\hline 32 & Hutan Walitis & Kec. Selopampang & Potensi \\
\hline 33 & Curug Watu Wayang & Kec. Bulu & Potensi \\
\hline 34 & Curug Dadap & Kec. Kranggan & Potensi \\
\hline 35 & Curug Grenjeng & Kec. Kranggan & Potensi \\
\hline 36 & | Curug Thithang & Kec. Temanggung & Potensi \\
\hline 37 & Hutan Walitis & Kec. Selopampang & Potensi \\
\hline 38 & Wisata Gunung Sumbing & & Potensi \\
\hline
\end{tabular}

\begin{tabular}{|c|c|c|c|}
\hline \multicolumn{4}{|c|}{ OBYEK WISATA BUATAN } \\
\hline 1 & Embung Kledung & Kec. Kledung & Dikembangkan \\
\hline 2 & Rest Area Kledung & Kec. Kledung & Dikembangkan \\
\hline 3 & Monumen Meteorit Wonotirto & Kec. Bulu & Dikembangkan \\
\hline 4 & Pusat Ayam Cemani & Kec. Kedu & \\
\hline 5 & Pasar Papringan & Kec. Kedu & Dikembangkan \\
\hline 6 & $\begin{array}{l}\text { Embung Tuk Buntu } \\
\text { Tlogopucang }\end{array}$ & Kec. Kandangan & Potensi \\
\hline 7 & Pasar Buah & Kec. Pringsurat & Potensi \\
\hline 8 & Rest Area\&Pasar Bh Pringsurat & Kec. Pringsurat & Potensi \\
\hline 9 & Embung Abimanyu Ngropoh & Kec. Kranggan & Dikembangkan \\
\hline 10 & Taman Kali Progo & Kec. Kranggan & Potensi \\
\hline 11 & Monumen Bambang Sugeng & Kec. Temanggung & Potensi \\
\hline 12 & Taman Kartini & Kec. Temanggung & Dikembangkan \\
\hline 13 & Pikatan Water Park/Tirto Asri & Kec. Temanggung & Dikembangkan \\
\hline \multicolumn{4}{|c|}{ OBYEK WISATA/DAYA TARIK WISATA BUDAYA/SEJARAH } \\
\hline 1 & Makam R. Trenggono Kusumo & & Potensi \\
\hline 2 & \begin{tabular}{|l} 
Situs Liyangan \\
\end{tabular} & Kec. Ngadirejo & Dikembangkan \\
\hline 3 & Candi Pringapus & Kec. Ngadirejo & Dikembangkan \\
\hline 4 & Endong Sewu & & Potensi \\
\hline 5 & Wisata Tirto Aji & & Dikembangkan \\
\hline 6 & Prasasti Gondosuli & Kec. Bulu & Potensi \\
\hline 7 & Makam Ki Ageng Makukuhan & Kec. Kedu & Potensi \\
\hline 8 & Masjid Menggoro & Kec. Tembarak & Potensi \\
\hline 9 & Makam Kyai Pahing & & Potensi \\
\hline \multicolumn{4}{|c|}{ OBYEK WISATA/DTW DESA WISATA } \\
\hline & & & \\
\hline
\end{tabular}


Sumber: Renja Dinas Kebudayaan dan Pariwisata Kab. Temanggung; 2021

Melihat data pariwisata yang berada di Kabupaten Temanggung sangatlah beragam. Hal tersebut diharapkan mampu memberikan peluang kepada masyarakat Temanggung untuk mengelola destinasidestinasi yang berada di sekitarnya. Berbagai jenis wisata di Kabupaten Temanggung tidak memungkiri bahwa hal ini akan mempengaruhi perekonomian masyarakat setempat, sehingga masyarakat juga mengandalkan sektor pariwisata untuk menunjang perekonomian. Meskipun bukan sebagai pekerjaan utama namun hal tersebut bermanfaat oleh masyarakat sekitar untuk menyokong kehidupan sehari-hari.

Namun hal tersebut menjadi berubah setelah munculnya pandemi covid19 yang tengah melanda Indonesia dan dunia sejak akhir tahun 2019, tepatnya pada bulan Desember. Pandemi yang tengah melanda saat ini memberikan pengaruh yang signifikan terhadap seluruh sektor suatu negara. Terkhususnya dalam hal ini adalah sektor pariwisata yang dapat menunjang perkembangan ekonomi suatu negara. Kegiatan pariwisata saat ini mengalami penurunan yang signifikan diantaranya dikarenakan adanya pembatasan bepergian seperti yang telah dicanangkan oleh Pemerintah dalam kebijakannya untuk mengurangi penyebaran covid-19 di Indonesia. Kebijakan-kebijakan yang diberlakukan kepada seluruh masyarakat Indonesia menjadikan masyarakat harus senantiasa menjalankan kebijakan yang telah dicanangkan tersebut. Selain pembatasan bepergian, Pemerintah Pusat juga memberikan kebijakan untuk menutup tempat-tempat wisata maupun tempattempat yang dapat menimbulkan kerumunan (covid19.go.id; 1 April 2020).

Selain itu Pemerintah Kabupaten Temanggung juga menerapkan kebijakan lain seperti yang tertuang dalam Peraturan Bupati Temanggung Nomor 45 Tahun 2020 tentang Penerapan Disiplin dan Penegakan Hukum Protokol Kesehatan Sebagai Upaya Pencegahan dan Pengendalian Corono Virus Disease 2019 (Covid-19). Pemberlakukan peraturan tersebut diharapkan untuk dapat dilaksanakan oleh seluruh masyarakat di Kabupaten Temanggung dalam melaksanakan aktivitasnya sehari-hari. Dalam Peraturan Bupati tersebut juga disampaikan sanksi-sanksi yang harus dipenuhi apabila masyarakat luas maupun 
pelaku usaha, pengelola wisata, serta penyelenggara kegiatan tanpa terkecuali.

Kebijakan tersebut memang dijalankan oleh pelaku atau pengelola sektor Pariwisata. Namun dengan adanya hal tersebut memberikan dampak terhadap pendapatan suatu destinasi wisata. Salah satunya adalah destinasi wisata Pikatan Water Park yang berada di Kabupaten Temanggung. Manager dari Pikatan Water Park menyampaikan bahwa selama masa pandemi pendapatan menurun yang mana setiap hari ada pemasukan sekitar 20 juta hinga 30 juta, hal tersebut dikarenakan pendapatan utama berasal dari pengunjung, namun adanya pademi dan kebijakan pembatasan yang diterapkan maka tidak ada wisatawan yang mengunjungi Pikatan Water Park (temanggungkab.go.id; 2020). Selain itu adanya pandemi covid-19 serta diberlakukannya pembatasan bepergian yang dicanangkan oleh Pemerintah menyebabkan beberapa perusahaan merumahkan pekerjanya. Di Kabupaten Temanggung telah ada 1.205 pekerja yang dirumahkan, baik dari sektor pariwisata, retail, kontruksi. Pekerja yang dirumahkan tersebut menambah angka pengangguran warga (mediaindonesia.com; 19 April 2020).
Kebijakan untuk merumahkan pekerja dikarenakan banyaknya tempat wisata yang ditutup sehingga pendapatan dari destinasi yang menurun menyebabkan pengelola kesusahan dalam membayarkan upah pekerja. Adanya kebijakan tersebut diharapkan mampu memberikan kemudahan bagi pengelola serta pekerja untuk saling memahami dan mengerti yang disebabkan adanya pandemi covid-19. Berbagai kebijakan telah dicanangkan dalam rangka mengurangi penyebaran covid-19. Namun diperlukan pula strategi maupun kebijakan yang diperlukan untuk memulihkan sektor pariwisata yang mana berpengaruh dalam perkembangan suatu negara. Stakeholder terkait hendaknya mencanangkan ide-ide dalam pemulihan sektor pariwisata.

Dalam memulihkan sektor pariwisata di Kabupaten Temanggung memiliki beberapa langkah yang dilakukannya. Langkah yang telah dilakukan diantaranya adalah Pemerintah Jawa Tengah melalui Kabupaten Temanggung memberikan stimulus kepada desa wisata sejumlah 11 desa wisata yang terdiri dari 4 desa wisata berkembang dengan jumlah anggaran sebesar Rp. 500 juta per desa wisata dan Rp. 100 juta per desa wisata untuk 7 desa wisata rintisan. Adanya 


\section{Sabbhata Yatra}

Jurnal Pariwisata dan Budaya

Volume 2 Nomor 2 Desember 2021

stimulus tersebut diharapkan pengelola

mematuhi protokol kesehatan serta dapat mengembangkan potensi yang dimiliki oleh masing-masing desa wisata (mediacenter.temanggungkab.go.id; 14 Agustus 2021).

Selain itu Dinas Kebudayaan dan Pariwisata Kabupaten Temanggung melakukan kerjasama dengan LKP Smile Zone Temanggung dalam rangka meningkatkan manajemen pengelolaan destinasi wisata serta melaksanakan pelatihan-pelatihan bagi pengelola pariwisata di Kabupaten Temanggung. Pelatihan-pelatihan yang dicanangkan seperti pelatihan digitalisasi pemasaran peningkatan inovasi sajian kuliner, kebersihan lingkungan dan pengelolaan sampah, pengelolaan toilet, keamanan dan keselamatan yang mana kegiatan tersebut dilakukan satu (1) minggu sekali dengan berbeda-beda tempat pelaksanaan (gatra.com; 27 Oktober 2021). Pemerintah Kabupaten Temanggung melakukan berbagai strategi dalam rangka mempertahankan sektor pariwisata sehingga berjalan dengan baik dan lancar tanpa harus melakukan penutupan destinasi wisata yang disebabkan adanya pandemi covid-19. Selain itu pengunjung yang mendatangi tempat wisata diharapkan untuk dapat selalu

mengenakan masker. Apabila ingin berfoto, wisatawan dapat melepas masker sebentar namun dengan melihat kondisi sekitar apakah banyak wisatawan yang datang maka lebih baik untuk tetap mengenakan masker.

\section{KESIMPULAN}

Pemerintah

Kabupaten Temanggung melakukan berbagai strategi kesiapan dalam pelaksanaan tata cara baru kegiatan pariwisata. Strategi yang disiapkan diantaranya adalah menerapkan kebijakan disiplin wisatawan dalam mengunjungi destinasi wisata seperti tetap mengenakan masker saat berfoto. Mendistribusikan Surat Edaran Bupati Temanggung yang menjabarkan sekaligus sanksi yang berkaitan dengan pelanggar peraturan. Selain itu Dinas Kebudayaan dan Pariwisata mengadakan pelatihan-pelatihan bagi pengelola destinasi wisata dalam rangka pengembangan manajemen destinasi wisata dengan menerapkan era baru yaitu era digitalisasi. Pelatihan-pelatihan tersebut diantaranya adalah pelatihan digitalisasi pemasaran, peningkatan inovasi sajian kuliner, kebersihan lingkungan dan pengelolaan sampah, pengelolaan toilet, keamanan dan keselamatan. Serta kerjasama 
Sabbhata Yatra

Jurnal Pariwisata dan Budaya

Volume 2 Nomor 2 Desember 2021

dengan Pemerintah Pusat dalam rangka meningkatkan anggaran untuk pemenuhan pengembangan potensi destinasi wisata.

\section{DAFTAR PUSTAKA}

Herabudin. (2016). Studi Kebijakan Pemerintah "Dari Filosofi ke Implimentasi”. Bandung: Pustaka Setia.

Rencana Kerja Dinas Kebudayaan dan Pariwisata Kabupaten Temanggung. 2021.

Surat Edaran Nomor SP/174/360/01/V/2021 terkait dengan Perpanjangan Penerapan Pemberlakuan Pembatasan Kegiatan Masyarakat (PPKM) Berbasis Mikro untuk Pengendalian Penyebaran Corona Virus Disease 2019 (Covid-19) di Kabupaten Temanggung

https://www.google.com/url?sa=t\&rct=j\&q= \&esrc $=s \&$ source $=w e b \& c d=\& c a d=r j a$ \&uact=8\&ved=2ahUKEwiosqGz 9T0 AhXq6XMBHRDCCQQQFnoECAcQ AQ\&url=https\%3A\%2F\%2Fppid.tema nggungkab.go.id\%2Fassets\%2Ffile_m aster\%2FSurat_PPKM 7.pdf\&usg=A OvVaw1uT3uBIDCBWOmnnC7LjxQ $\underline{\mathrm{V}}$ diakses pada 3 Desember 2021.

Suwitri, Sri. (2008). Konsep Dasar Kebijakan Publik.

https://www.academia.edu/download/57623

163/PDFkebiajakan_publik.pdf diakses pada 5 Desember 2021.

Peraturan Bupati Temanggung Nomor 45 Tahun 2020 tentang Penerapan Disiplin dan Penegakan Hukum
Protokol Kesehatan Sebagai Upaya Pencegahan dan Pengendalian Corono Virus Disease 2019 (Covid-19)

https://covid19.hukumonline.com/wpcontent/uploads/2021/07/peraturan bu pati_temanggung_nomor_45 tahun_2 020.pdf diakses pada 3 Desember 2021

Anonim. 2015. Sekilas Temanggung. https://portal.temanggungkab.go.id/info/deta $\mathrm{il} / 2 / 17 /$ sekilas-temanggung.html diakses pada 3 Desember 2021.

Anonim. 2020. Kebijakan PSBB Pilihan Paling Rasional di Tengah Covid-19

https://covid19.go.id/p/berita/kebijakanpsbb-pilihan-paling-rasional-ditengah-covid-19 diakses pada 2 Desember 2021.

Anonim. 2020. Industri Pariwisata Temanggung Tenggelam karena Covid-19, Pikatan Water Park Nihil Pendapatan.

hebat.temanggungkab.go.id/news/1827155 diakses pada 2 Desember 2021.

Anonim. 2020. 1205 Warga Temanggung Kehilangan Pekerjaan Akibat Covid19

https://mediaindonesia.com/nusantara/30537 0/1205-warga-temanggungkehilangan-pekerjaan-akibat-covid-19 diakses pada 8 Desember 2021.

Anonim. 2021. Sebelas Desa Wisata Dapat Stimulus Dana Pengembangan https://mediacenter.temanggungkab.go.id/be rita/detail/sebelas-desa-wisata-dapatstimulus-dana-pengembangan diakses pada 8 Desember 2021.

anonim. 2015. Potensi Wisata

https://portal.temanggungkab.go.id/info/deta il/4/53/pariwisata.html diakses pada 1 Desember 